\title{
Studies on Preparation of Buns Fortified with Germinated Horse Gram Flour
}

\author{
Chandralekha Bhokre ${ }^{1}$, Pravin Udhavrao Ghatge ${ }^{1 *}$, Girish Machewad ${ }^{2}$ and Ashok Rodge ${ }^{1}$
}

${ }^{1}$ Department of Food Chemistry and Nutrition, College of Food Technology, Marathwada Krishi Vidyapeeth, Parbhani - 431402, India ${ }^{2}$ Department of Food and Industrial Microbiology, College of Food Technology, Marathwada Krishi Vidyapeeth, Parbhani - 431 402, India

\begin{abstract}
The horse gram is a cheapest source of protein, calcium and iron. Further the germination of horse gram seeds can reduce the anti-nutritional factors. The germination was carried out by washing, soaking $(8 \mathrm{~h})$, germination period $(24 \mathrm{~h})$, and oven drying $\left(50^{\circ} \mathrm{C}\right)$ and ground into flour in hammer mill. The effect of germination on chemical characteristics of horse gram was found significant decrease $(P>0.05)$ in protein, carbohydrate, fat and significant increase $(P<0.05)$ in moisture and ash content. Further value added product (buns) was prepared incorporation of $(5 \%, 10 \%, 15 \%$ and $20 \%)$ with germinated horse gram flour (GHF) by straight dough method. The sensory evaluation of buns was carried out by a panel of ten trained using 9-point Hedonic scale. The sensory quality of bun were significantly decreased $(P>0.05)$ for higher level of GHF and significantly increased $(P<0.05)$ for low level of GHF. The buns prepared by incorporation of GHF up to $10 \%$ were acceptable without affecting organoleptic quality.
\end{abstract}

Keywords: Buns; Germination; Chemical characteristics; Sensory quality

\section{Introduction}

The horse gram (Dolichos biflorus L.) commonly known as kulthi is a traditional unexploited tropical grain legume and well known for its hardiness, adaptability to poor soil and adverse climatic conditions. The horse gram is a cheapest source of protein. Further it is also rich in minerals such as calcium. The chemical composition is comparable with commonly cultivated legumes. Like other legumes, this is deficient in methionine and tryptophan. Horse gram is an excellent source of iron and molybdenum. Comparatively, horse gram seeds have higher trypsin inhibitor and hemagglutinin activities and polyphenols than moth bean seeds. Dehusking, germination, cooking, and roasting have been shown to produce beneficial effects on nutritional quality of the legume [1]. The germination is a simple method of food processing that result in increased nutritive value and decreases the phytates, tannin level and increases the availability of iron and calcium [2].

The buns are yeast leavened food like bread. Further the requirement of raw materials as well as the procedure in case of buns is similar to those of bread except buns are rounded and moulded with bun moulders. The wheat flour is major ingredient of bun and it is well reported that in fortifying wheat flour with high lysine material specially legume flour to increase the protein content [3]. Thus efforts have made to prepare germinated horse gram flour (GHF) to reduce the anti-nutritional factor and prepare buns with the incorporation of germinated horse gram flour to increase its protein content with acceptable organoleptic quality.

\section{Materials and Methods}

The horse gram seeds procured from the Project Coordinator, AICRP on Arid Legume, Jodhpur.

\section{Preparation of GHF}

The seeds were washed in tap water, soaked in the mercuric chloride solution (0.1\%) for period (3-4 $\mathrm{min}$ ) and then washed thoroughly with distilled water until free from chloride ions. Further the seeds were soaked in distilled water of depth $(3-4 \mathrm{~cm})$ at room temperature for the period $(8 \mathrm{~h})$. The water was changed thrice and then seeds were placed in glass trays covered with wet muslin cloth and allowed to germinate for the period $(24 \mathrm{~h})$. The germination of the horse gram was carried out as per standard method [4]. The germinated horse gram seeds were dried in oven $\left(50^{\circ} \mathrm{C}\right)$ for period $(5-6 \mathrm{~h})$.The dried germinated horse gram seeds was ground in hammer mill (Milcent, Anand. Gujarat. India).

\section{Preparation of buns fortified with GHF}

The prepared GHF was used for buns preparation. The buns were prepared by straight dough method (Figure 1). The recipe for preparation of buns fortified with GHF (Table 1). The buns were prepared by incorporation of GHF (Table 2).

\section{Determination of chemicals characteristics of horse gram} and germinated horse gram seeds

The chemicals characteristics such as moisture content, carbohydrate, protein, lipid and ash were determined as per standard procedure [5]

\section{Organoleptic evaluation}

The sensory evaluation buns fortified with varying levels germinated horse gram flour on sensory quality of buns was carried out by trained panel of ten judges on a 9.0 point Hedonic scale [6].

\section{Statistical analysis}

The data generated in the experiments were recorded and subjected to statistical analysis using standard procedure [7]. The standard

*Corresponding author: Pravin Udhavrao Ghatge, Department of Food Chemistry and Nutrition, College of Food Technology, Marathwada Krish Vidyapeeth, Parbhani - 431 402, India; Tel: +91 02452 222468; Fax: +91 02452 234150; E-mail: pughatge@indiatimes.com

Received June 07, 2012; Published June 25, 2012

Citation: Bhokre C, Ghatge PU, Machewad G, Rodge A (2012) Studies on Preparation of Buns Fortified with Germinated Horse Gram Flour. 1: 127. doi:10.4172/scientificreports.127

Copyright: ( 2012 Bhokre C, et al. This is an open-access article distributed unde the terms of the Creative Commons Attribution License, which permits unrestricted use, distribution, and reproduction in any medium, provided the original author and source are credited. 
Citation: Bhokre C, Ghatge PU, Machewad G, Rodge A (2012) Studies on Preparation of Buns Fortified with Germinated Horse Gram Flour. 1: 127. doi:10.4172/scientificreports.127

Page 2 of 3

errors (SE) and critical differences (CD) at 5\% level of significance were worked out for comparison of treatments and presented in the respective tables.

\section{Results and Discussion}

The effect of germination on chemical characteristics of horse gram was found increased in moisture content and ash of horse gram from $10.18-10.40 \%$ and $2.88-3.10$ respectively during germination the period $(24 \mathrm{~h})$ (Table 3$)$. The protein content of horse gram was found decreased from $26.50-26.1 \%$. This is due to utilization of amino acid and peptides during growth and increase in proteolytic activity [8]. The carbohydrate and lipid content were found slightly decreased during germination of the horse gram seeds. This is because of increase in amylase and lipase activity. The nonsignificant increase in ash content was observed.

The sensory evaluation of buns fortified with GHF scored less than the control sample (Table 4). Further the sensory quality attributes scored less value for higher level of GHF and increased for low level of GHF fortified buns respectively. The buns fortified with GHF (5 10\% and 15\%) were acceptable than the buns fortified with GHF (20\%). The buns fortified with GHF $(20 \%)$ significantly affected $(\mathrm{P}<0.05)$ the colour of crust and crumb, texture and flavour. Finally it can be

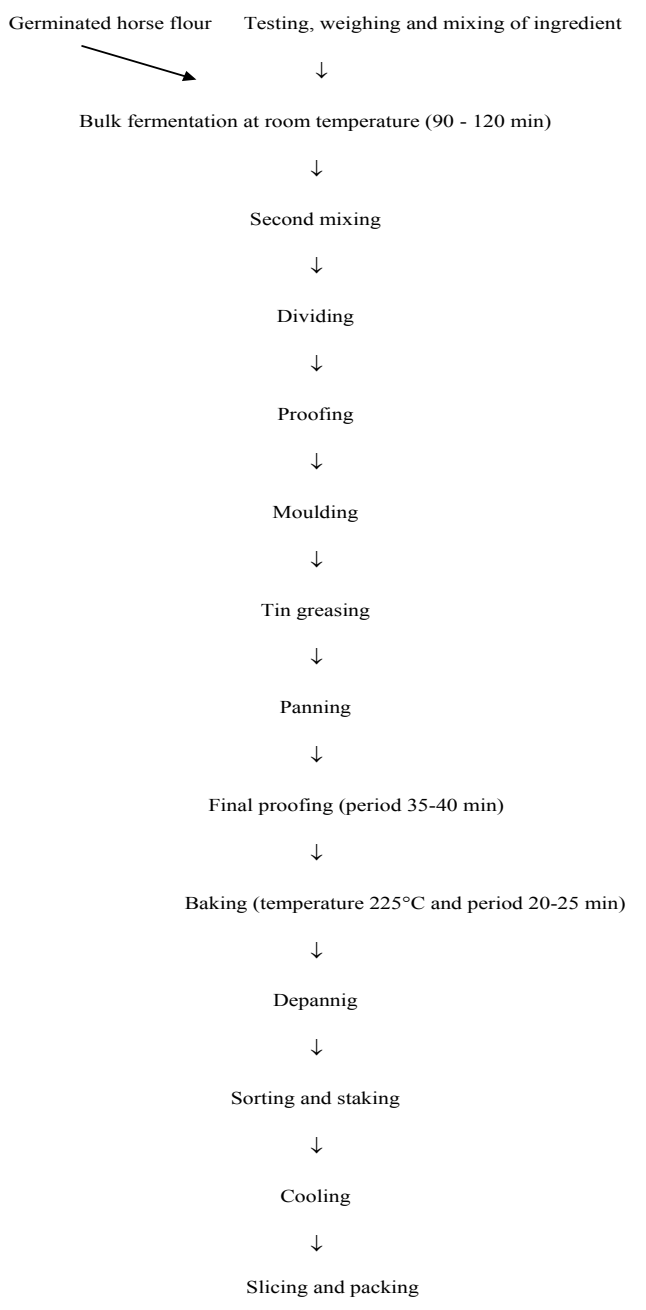

Figure 1: Flow sheet for preparation of buns fortified with GHF.

\begin{tabular}{|c|c|}
\hline Particulars & Quantity \\
\hline Maida $(\mathrm{g})$ & 100 \\
\hline Yeast $(\mathrm{g})$ & 2.5 \\
\hline Sugar $(\mathrm{g})$ & 4.0 \\
\hline Fat $(\mathrm{g})$ & 3.5 \\
\hline Water $(\mathrm{mL})$ & 60 \\
\hline GMS $(\mathrm{g})$ & 0.5 \\
\hline Calcium propionate $(\mathrm{g})$ & 0.5 \\
\hline Salt $(\mathrm{g})$ & 1.5 \\
\hline Milk powder $(\mathrm{g})$ & 0.5 \\
\hline
\end{tabular}

Table 1: Recipe for preparation of buns fortified with GHF.

\begin{tabular}{|c|c|c|c|c|c|}
\hline \multirow{2}{*}{ Particulars } & \multicolumn{5}{|c|}{ Germinated horse gram flour (\%) } \\
\cline { 2 - 6 } & A & B & C & D & E \\
\cline { 2 - 6 } & 0 & 5 & 10 & 15 & 20 \\
\hline Maida & 100 & 95 & 90 & 85 & 80 \\
\hline Germinated horse gram flour & - & 5 & 10 & 15 & 20 \\
\hline
\end{tabular}

Table 2: The levels of GHF replaced with maida in the preparation of buns.

\begin{tabular}{|c|c|c|c|c|}
\hline Parameters & Horse gram & $\begin{array}{c}\text { Germinated horse } \\
\text { gram seeds }\end{array}$ & SE \pm & CD at 5\% \\
\hline Moisture (\%) & 10.18 & 10.40 & 0.052 & 0.20 \\
\hline Protein (\%) & 26.50 & 26.10 & 0.045 & 0.178 \\
\hline Lipid (\%) & 1.65 & 1.56 & 0.026 & 0.102 \\
\hline Carbohydrate (\%) & 58.40 & 58.01 & 0.028 & 0.113 \\
\hline Ash (\%) & 2.88 & 3.10 & 0.026 & 0.102 \\
\hline
\end{tabular}

$\mathrm{SE}$, standard error of the mean; $\mathrm{CD}$, critical difference.

Each value is average of three determinations.

Table 3: Effect of germination on chemical characteristics of horse gram seeds.

\begin{tabular}{|c|c|c|c|c|c|c|}
\hline Buns & Volume & Crust color & Crumb color & Texture & Flavor & $\begin{array}{c}\text { Overall } \\
\text { acceptability }\end{array}$ \\
\hline A & 8.30 & 8.60 & 8.52 & 8.54 & 8.40 & 8.47 \\
\hline B & 7.86 & 7.82 & 7.74 & 7.80 & 7.70 & 7.78 \\
\hline C & 7.80 & 7.80 & 7.70 & 7.75 & 7.70 & 7.75 \\
\hline D & 7.00 & 6.90 & 6.90 & 7.10 & 7.10 & 7.00 \\
\hline E & 6.90 & 6.00 & 6.00 & 6.30 & 6.30 & 6.30 \\
\hline SE \pm & 0.041 & 0.039 & 0.043 & 0.038 & 0.056 & 0.024 \\
\hline CD at 5\% & 0.131 & 0.106 & 0.137 & 0.120 & 0.177 & 0.075 \\
\hline
\end{tabular}

SE, standard error of the mean; CD, critical difference.

Each value is average of three determinations.

Table 4: Effect of germinated horse gram flour on sensory quality of buns.

concluded that the buns fortified with GHF were found to contain high amount of proteins, minerals and sensory qualities were found acceptable.

\section{References}

1. Kadam SS, Salunkhe DK (1985) Nutritional composition, processing, and utilization of horse gram and moth bean. Crit Rev Food Sci Nutr 22: 1-26

2. Borade VP, Kadam SS, Salunkhe DK (1984) Changes in phytates phosphorus and minerals during germination and cooking of horse gram and moth bean Plant Foods Human Nutr 34: 151-157.

3. Pomeranz Y (1970) Protein-enriched bread. CRC Critical Reviews in Food Technol 1: 453-478.

4. Sawant RR (2007) Preparation of value added extruded product by using germinated horse gram flour. M. Tech. Thesis, College of Food Technology. Marathwada Krishi Vidyapeeth, Parbhani, Maharashtra, India.

5. AOAC (2000) Official Methods of Analysis (17th Edn.), Official Methods of Analysis of Association of Official Agricultural Chemists International, Gaithersburg, MD. 
Citation: Bhokre C, Ghatge PU, Machewad G, Rodge A (2012) Studies on Preparation of Buns Fortified with Germinated Horse Gram Flour. 1: 127. doi:10.4172/scientificreports. 127

Page 3 of 3

6. Amerine MA, Pangborn RM, Roessler EB (1965) Principles of sensory evaluation of food. Academic press, New York.

7. Snedecor GW, Cochran WG (1989) Statistical Methods, 8th ed. lowa State University Press, Ames, IA
8. Ismail S, Wankhede DB, Syed HM, Kulkarni AS, Fayazuddin M (2003) The effect of germination on the changes in protein, free amino acid and in vitro protein digestibility of moth bean and horse gram. Proceedings of the National Symposium on Arid Legumes for Food Nutrition Security and Promotion of Trade, 315-317. 